\title{
Evaluation of Anti-HBs Antibody Immune Response against Hepatitis B virus in Vaccinated People in a North-eastern Bulgaria Region
}

Denitsa T. Tsaneva-Damyanova ${ }^{1,3}$, Liliya I. Ivanova ${ }^{1,2}$, Silviya N. Pavlova ${ }^{4}$, Svetlana B. Todorova ${ }^{5}$, Tsvetelina K. Popova ${ }^{2,6}$

${ }^{1}$ Department of Microbiology and Virology, Medical University, Varna, Bulgaria

${ }^{2}$ Laboratory of Clinical Virology, St Marina University Hospital, Varna, Bulgaria

${ }^{3}$ Status Medical Diagnostic Laboratory, Varna, Bulgaria

${ }^{4}$ Department of Social Medicine and Health Care Organization, Medical University, Varna, Bulgaria

${ }^{5}$ Department of Statistics and Applied Mathematics, Varna University of Economics, Varna, Bulgaria

${ }^{6}$ Education and Research Sectors of Medical Laboratory, Medical College, Medical University, Varna, Bulgaria

Corresponding author: Denitsa Tsaneva-Damyanova, Department of Microbiology and Virology, Medical University, 3 Bregalnitsa St., Varna, Bulgaria; E-mail: dr.tsaneva@gmail.com; Tel.: 0878877627

Received: 19 Feb $2019 \diamond$ Accepted: 15 Apr $2019 \diamond$ Published: 31 Dec 2019

Citation: Tsaneva-Damyanova DT, Ivanova LI, Pavlova SN, Todorova SB, Popova TK. Evaluation of anti-HBs antibody immune response against hepatitis B virus in vaccinated people in North-Eastern Bulgaria region. Folia Med (Plovdiv) 2019;61(4):572-78. doi: 10.3897/ folmed.61.e47760.

\section{Abstract}

Introduction: Hepatitis B virus (HBV) is one of the most significant human pathogens responsible for a huge number of acute and chronic liver infectious diseases worldwide.

Aim: To find the duration of post-vaccination immune response in individuals allocated to five age groups from 6 months to 20 years.

Materials and methods: All tested subjects were born between 1999 and 2018 and therefore covered by the compulsory vaccination program against hepatitis B. For the serological marker anti-HBs Ab we investigated 449 serum samples taken from ambulatory people and patients of St Marina University Hospital in Varna.

Results: A positive antibody response (anti-HBs $\mathrm{Ab}>10 \mathrm{mIU} / \mathrm{ml})$ was reported in $79.7 \%(\mathrm{n}=51)$ of the group of subjects up to one year old, in $70.0 \%(\mathrm{n}=196)$ of the subjects in the age range 1 year/1 month to 15 years, and in $39.3 \%(\mathrm{n}=33)$ of the subjects 15 years $/ 1$ month to 20 years old. Female sex had a better post-vaccination response than male sex with statistically significant relationship between sex and anti-HBs Ab titer $\left(\chi^{2}=24.76, \mathrm{p}<0.01\right)$.

Conclusions: Regardless of the mass immunization against HBV in Bulgaria, the relative share of chronic HBV infections does not show a downward trend. Therefore, it is very important to study the duration of the post-vaccination immune response by demonstrating the anti-HBs antibodies and to apply a booster dose from the vaccine if needed.

\section{Keywords}

anti-HBs Ab, HBV, HBV vaccination

Copyright by authors. This is an open access article distributed under the terms of the Creative Commons Attribution License (CC-BY 4.0), which permits unrestricted use, distribution, and reproduction in any medium, provided the original author and source are credited. 


\section{INTRODUCTION}

Hepatitis B virus is one of the most significant human pathogens, responsible for a huge number of acute and chronic liver diseases. Complications of HBV infection have $66 \%$ relative share of all reported death cases from viral hepatitis worldwide. ${ }^{1}$ Bulgaria is in the intermediate endemic area, where $2 \%(3 \%-5 \%)$ of the population are carriers of $\mathrm{HBsAg}$, ranging from $1.9 \%$ to $5.3 \%$ for different regions across the country. ${ }^{2}$ Markers for $\mathrm{HBV}$ infection can be found in $20 \%-60 \%$ of the people. ${ }^{3}$ A survey conducted in Eastern Bulgaria reported the presence of 548 new cases of HBV between 2008 and 2014 as there has been at least a 3 -fold decline in the prevalence of HBV incidence in these regions. The age structure of $\mathrm{HBV}$ infection in Bulgaria shows markedly higher relative share in the age groups 19 - 29 - 39 years. Young people around the age of 20 are the most vulnerable group, as only a part of them are included in the compulsory vaccination program. ${ }^{4} \mathrm{HBV}$ is an etiological agent of $30 \%$ of chronic hepatitis in North-eastern Bulgaria and about $15 \%$ of all acute viral hepatitis. ${ }^{5}$

$\mathrm{HBV}$ infection is a vaccine-preventable anthroponosis and as for its clinical and social significance, in 1991 the WHO appealed for vaccination of all healthy newborn children. ${ }^{6}$ Vaccination against HBV is a highly effective measure for disease prevention and control, although we still cannot talk about global virus eradication. By the end of 2017, vaccines had been administered in 187 countries, with a global coverage of $84 \% .{ }^{1}$ Most of the countries use mainly recombinant vaccines. The vaccine against $\mathrm{HBV}$ is used in 20 of the 27 countries in the European Union.? Compulsory vaccination of new-borns in Bulgaria was carried out from 1991 on with recombinant HBV vaccines. Yet, there are only a few studies evaluating the protection after the vaccination against hepatitis B, especially in children. ${ }^{8}$ According to national statistics, the scope of hepatitis B vaccine among Bulgarian infants in 1992 and 2001 was $71 \%$ and $93 \%$, respectively. ${ }^{9}$ The aim of our study was to find the duration of post-vaccination immune response in vaccinated individuals allocated into five age groups (range 6 months to 20 years). All included subjects were born between 1999 and 2018 and therefore were covered by the compulsory vaccination program against hepatitis $B$ applied in Bulgaria.

\section{MATERIALS AND METHODS}

\section{STUDY POPULATION}

As many as 449 serum samples were investigated in a retrospective study - 58.8\% of them (95\% CI: $54.1 \%-63.4 \%$, n $=264$ ) were ambulatory patients and $41.2 \%$ (95\% CI: $36.6 \%$ $-45.9 \%, \mathrm{n}=185)$ - patients treated in St Marina University Hospital in Varna. The serum samples were tested in the hospital's laboratory of clinical virology and in Status diagnostic laboratory in Varna. Inclusion criteria: the included subjects were primarily from ambulatory population covered by the compulsory vaccination against $\mathrm{HBV}$ with all the data necessary for the statistical processing. Anti-HBs $\mathrm{Ab}$ titres were measured after the full course of mandatory vaccination against $\mathrm{HBV}$ in Bulgaria. The analysis excluded subjects positive for $\mathrm{HBsAg}$ and anti-HBc total $\mathrm{Ab}$ markers without data allowing statistical interpretation, as well as people with a booster dose of the HBV vaccine. The study excluded subjects that were hospitalised in infectious clinics for acute viral hepatitis.

The subjects were divided into 5 age groups: Group 1 (6 months - 1 year) - $14.3 \%$ (95\% CI: $11.2 \%-17.8 \%, \mathrm{n}=64)$; group 2 (1 year/ 1 month - 5 years) - 20.0\% (95\% CI: $16.4 \%$ $-24.1 \%, \mathrm{n}=90)$; group 3 (5 year/1 month to 10 years) $24.5 \%$ (95\% CI: $20.6 \%-28.7 \%, \mathrm{n}=110)$; group 4 ( 10 years $/ 1$ month to 15 years) - $21.6 \%$ (95\% CI: $17.9 \%$ - 25.7\%, $\mathrm{n}=97$ ); and group 5 (15 years/ 1 month to 20 years) - 19.6\% (95\% CI: $15.9 \%-23.3 \%, \mathrm{n}=88)$.

The relative share of investigated females - 52.8\% (95\% CI: $48.0 \%-57.5 \%, \mathrm{n}=237$ ) was higher than the relative share of the investigated males - $47.2 \%$ (95\% CI: $42.5 \%$ $52.0 \%)$.

We used EIAs- ELISA and CLIA (chemiluminescent immunoassay technology) to detect anti-HBs Ab. ELISA test (anti HBs Ab Dia.PRO, Milano, Italy) is an enzyme sandwich ELISA test for quantification of antibodies to the surface antigen of hepatitis B virus in human plasma and/ or serum. Serum samples with concentration greater than $10 \mathrm{mIU} / \mathrm{ml}$ were considered positive. A value of specificity of $100 \%$ was assessed and a diagnostic sensitivity of $99.7 \%$ was found for the test. The LIAISON ${ }^{\oplus}$ XL MUREX anti-HBs (DiaSorin) test was done via CLIA technology in order to quantify anti-HBs antibodies in human serum or plasma samples. The principle of this test of quantifying anti-HBs is a direct, sandwich-chemiluminescent immunoassay. A value of specificity of $100 \%$ was assessed and a diagnostic sensitivity of $100.0 \%$ was found for the test. Both types of tests were performed according to manufacturer's recommendations. An adequate protective immune response was provided when anti-HBs Ab titer was greater than 100 $\mathrm{mIU} / \mathrm{ml}$, one month after administration of the last dose of the vaccine.

\section{ETHICS STATEMENT}

The conducted studies and the corresponding results were coordinated and approved by the Ethics Committee at the Medical University, Varna.

\section{StATISTICAL ANALYSIS}

Statistical analyses were performed using SPSS v.23. Results were expressed as mean $\pm \mathrm{SD}$ or median (range) as appropriate and confidence intervals (95\% CI) were determined. Data were analyzed with t-test, Pearson's $\chi^{2}$ test, and Spearman rank correlation $(r)$. Cramer $(V)$ test was used to search for associations in the category data and values from 0 to +1 . Two-sided $p$-values $<0.05$ were considered statistically significant. 


\section{RESULTS}

Positive immune response (anti-HBs $\mathrm{Ab}>10 \mathrm{mIU} / \mathrm{ml}$ ) was found in individuals from all five age groups. The highest relative share of positive subjects was found in the range from 6 months to 15 years (Table 1). The difference in the relative shares of the positive individuals with the best immune response between the first and the last age groups was statistically significant $\left(\chi^{2}=81.98 ; p<0.01\right)$. Spearman rank correlation test showed a significant association but an inverse relationship between age and the immune response $(r=-0.337, p=0.001)$. This demonstrated that with age the post-vaccination immune response decreased or became undetectable with the available serological tests. The distribution of investigated people by age group and titre of anti$\mathrm{HBs} \mathrm{Ab}$ is presented in Fig. 1.

Individuals were allocated according to the titre of anti$\mathrm{HBs} \mathrm{Ab}$ (graph abscissa) in 4 groups. Individuals with an immune response of $10 \mathrm{mIU} / \mathrm{ml}$ (group 1), with an immune response of $10-50 \mathrm{mIU} / \mathrm{ml}$ (group 2), with an immune response of $50-100 \mathrm{mIU} / \mathrm{ml}$ (group 3) with an immune response of $100 \mathrm{mIU} / \mathrm{ml}$ (group 4). The age code 1 is for persons aged from 6 months to 1 year, code 2 - for those in the range 1 year $/ 1$ month - 5 years, code 3 - in the range 5 years $/ 1$ month - 10 years, code 4 for those in the range of 10 years $/ 1$ month - 15 years and code 5 for people in the range of 15 years/ 1 month - 20 years old.

As per the results above, we can summarize that a positive immune response up to 1 year old was found in $79.7 \%$ of the subjects $(n=51)$, in the age range of 1 year/ 1 month - 15 years anti-HBs positive were $65.1 \%(n=196)$ and in the range 15 -years/ 1 month -20 years the relative share of
anti-HBs positive people was $39.3 \%(\mathrm{n}=33)$.

The distribution of anti-HBs antibody immune response by gender is presented in Table 2 .

The chi-square analysis results for the entire observation period showed that differences in the anti-HBs Ab immune response by gender were significant. Female subjects had a better post-vaccination response than men, with the relationship between sex and anti-HBs Ab being statistically significant $\left(\chi^{2}=24.76, \mathrm{p}<0.01\right)$.

The distribution of the people according to the titre of anti-HBs Ab and sex are presented in Fig. 2, where men are marked with code 1 and women with code 2 . Absence of immune response $(\leq 10 \mathrm{mIU} / \mathrm{ml})$ was indicated via code 1 , from $10 \mathrm{mIU} / \mathrm{ml}$ to $50 \mathrm{mIU} / \mathrm{ml}$ - with code 2 , immune response from $50 \mathrm{mIU} / \mathrm{ml}$ to $100 \mathrm{mIU} / \mathrm{ml}$ - with code 3 , and immune response higher than $100 \mathrm{mIU} / \mathrm{ml}$ - with code 4 .

\section{DISCUSSION}

In 2009, a report on the HBV epidemiology in 10 European countries was published in relation to the application of the vaccination policies. At the time of publication of this report, HBV universal vaccination programs recommended by the WHO were in progress in different countries of eastern Europe (the Czech Republic, Romania, and Slovakia), but coverage differed between countries, most probably reflecting the difficulty to reach people living in rural areas in some countries such as Romania and Slovakia. ${ }^{10}$ In Poland, $\mathrm{HBV}$ vaccination of newborn babies is active and no new $\mathrm{HBV}$ cases in childhood and adolescence have been registered, whereas non-vaccinated subjects still show a high

Table 1. Distribution of people by age and anti-HBs antibody titre

\begin{tabular}{|c|c|c|c|c|c|c|c|c|c|c|}
\hline & \multirow{2}{*}{$\begin{array}{l}\text { Immune } \\
\text { response }\end{array}$} & & \multicolumn{5}{|c|}{ Age } & \multirow[t]{2}{*}{ Total } & \multirow[t]{2}{*}{ 95\% CI } & \multirow[b]{2}{*}{$\underset{\Omega}{\stackrel{\Xi}{\Xi}}$} \\
\hline & & & $6 \mathrm{~m} / 1 \mathrm{yr}$ & $\begin{array}{c}1 \mathrm{yr} / \\
1 \mathrm{~m}-5 \mathrm{yrs}\end{array}$ & $\begin{array}{c}5 \mathrm{yrs} / \\
1 \mathrm{~m}-10 \mathrm{yrs}\end{array}$ & $\begin{array}{c}10 \mathrm{yrs} / \\
1 \mathrm{~m}-15 \mathrm{yrs}\end{array}$ & $\begin{array}{c}15 \mathrm{yrs} / \\
1 \mathrm{~m}-20 \mathrm{yrs}\end{array}$ & & & \\
\hline \multirow{9}{*}{ 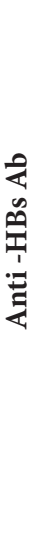 } & $<10 \mathrm{mIU} / \mathrm{ml}$ & $\mathrm{N}$ & 13 & 21 & 41 & 40 & 55 & 170 & & \multirow{9}{*}{$\begin{array}{l}\vec{\delta} \\
\dot{0} \\
\dot{v}\end{array}$} \\
\hline & & $\%$ & $20.3 \%$ & $23.3 \%$ & $37.3 \%$ & $41.2 \%$ & $62.5 \%$ & $37.9 \%$ & $33.4 \%-42.5 \%$ & \\
\hline & $10-50 \mathrm{mIU} / \mathrm{ml}$ & $\mathrm{N}$ & 13 & 28 & 34 & 40 & 25 & 140 & & \\
\hline & & $\%$ & $20.3 \%$ & $31.1 \%$ & $30.9 \%$ & $41.2 \%$ & $28.4 \%$ & $31.2 \%$ & $26.9 \%-35.7 \%$ & \\
\hline & $50-100 \mathrm{mIU} / \mathrm{ml}$ & $\mathrm{N}$ & 6 & 11 & 12 & 9 & 2 & 40 & & \\
\hline & & $\%$ & $9.4 \%$ & $12.0 \%$ & $10.9 \%$ & $9.3 \%$ & $2.3 \%$ & $8.9 \%$ & $6.4 \%-11.9 \%$ & \\
\hline & \multirow[t]{2}{*}{$>100 \mathrm{mIU} / \mathrm{ml}$} & $\mathrm{N}$ & 32 & 30 & 23 & 8 & 6 & 99 & & \\
\hline & & $\%$ & $50.0 \%$ & $33.3 \%$ & $20.9 \%$ & $8.2 \%$ & $6.8 \%$ & $22.0 \%$ & $18.3 \%-26.2 \%$ & \\
\hline & Total & $\mathrm{N}$ & 64 & 90 & 110 & 97 & 88 & 449 & & \\
\hline
\end{tabular}


Table 2. Distribution of tested subjects by gender and anti-HBs Ab immune response

\begin{tabular}{|c|c|c|c|c|c|c|c|}
\hline \multicolumn{3}{|c|}{ Immune response } & \multicolumn{2}{|c|}{ Gender } & \multirow[t]{2}{*}{ Total } & \multirow[t]{2}{*}{ 95\% CI } & \multirow[t]{2}{*}{ p value } \\
\hline & & & Male & Female & & & \\
\hline \multirow[t]{9}{*}{ Anti-HBs Ab } & $<10 \mathrm{mIU} / \mathrm{ml}$ & $\mathrm{N}$ & 104 & 66 & 170 & & \\
\hline & & $\%$ & $49.1 \%$ & $27.8 \%$ & $37.9 \%$ & $33.4 \%-42.5 \%$ & \\
\hline & $10-50 \mathrm{mIU} / \mathrm{ml}$ & $\mathrm{N}$ & 60 & 80 & 140 & & \\
\hline & & $\%$ & $28.3 \%$ & $33.8 \%$ & $31.2 \%$ & $26.9 \%-35.7 \%$ & \\
\hline & $50-100 \mathrm{mIU} / \mathrm{ml}$ & $\mathrm{N}$ & 17 & 23 & 40 & & $<0.001$ \\
\hline & & $\%$ & $8.0 \%$ & $9.7 \%$ & $8.9 \%$ & $6.4 \%-11.9 \%$ & \\
\hline & $>100 \mathrm{mIU} / \mathrm{ml}$ & $\mathrm{N}$ & 31 & 68 & 99 & & \\
\hline & & $\%$ & $14.6 \%$ & $28.7 \%$ & $22.0 \%$ & $18.3 \%-26.2 \%$ & \\
\hline & Total & $\mathrm{N}$ & 212 & 237 & 449 & & \\
\hline
\end{tabular}

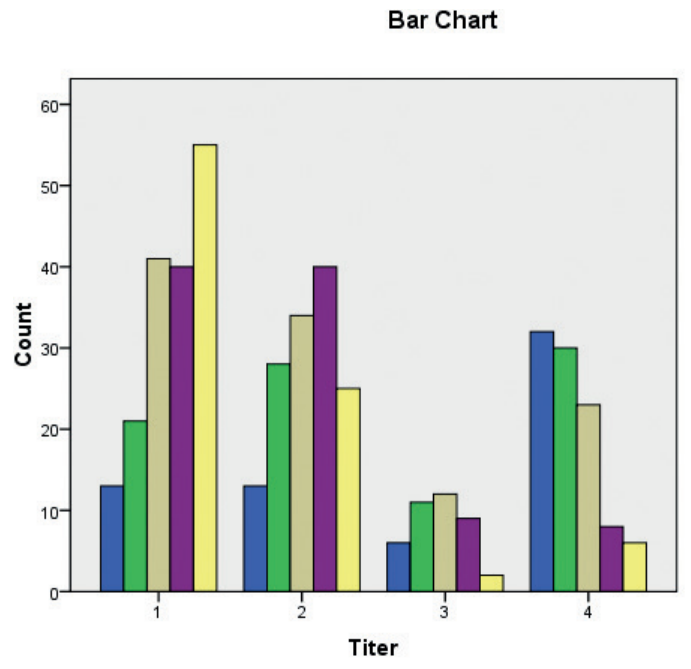

Figure 1. Age distribution of study participants by their anti-HBs Ab titre.

rate of acute $\mathrm{HBV}$ infection. ${ }^{11}$ The seroprofile for Romania, in this survey, demonstrates that although the reported coverage of infants with $\mathrm{HBV}$ vaccination was high (>95\%), a large percentage of children had no markers of vaccination - only $63 \%$ of children aged 3-4 years had serological evidence of vaccination. For Slovak children of 1 year of age the results showed that $85 \%$ were anti-HBs $\mathrm{Ab}$ positive $(>10 \mathrm{mIU} / \mathrm{ml})$, for Italy - more than $80 \%$, for Belgium nearly $80 \% .^{10}$

Our data confirmed the European trends in anti-HBs $\mathrm{Ab}$ seroconversion as we have reported an immune response in children up 1 year of age to be nearly $80 \%$. Recombinant vaccines cannot treat already established chronic hepatitis $\mathrm{B}$ but are effective and result in seroconversion (appear-

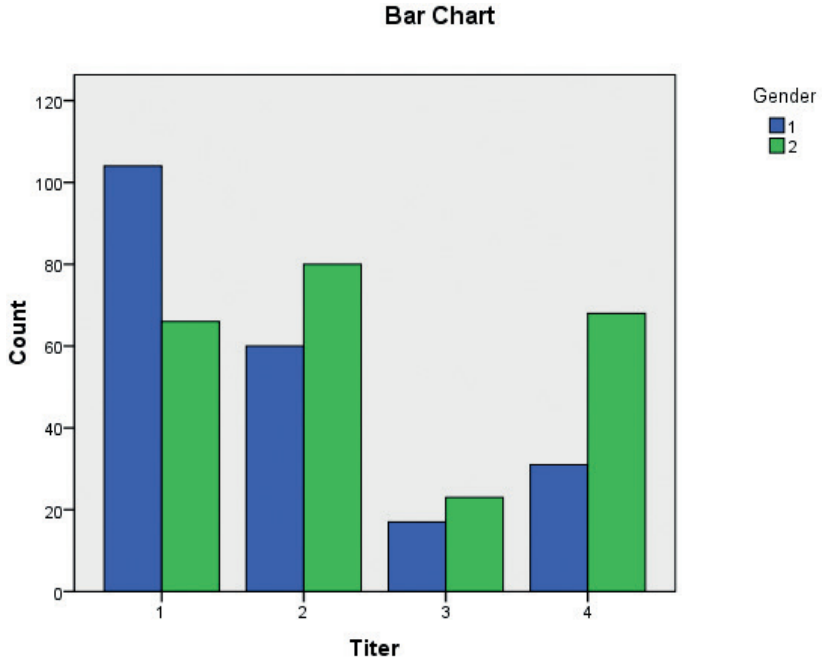

Figure 2. Gender and anti-HBs Ab titer.

ance of anti-HBs $\mathrm{Ab}$ ) in children and adults, decreasing the incidence of HBV infection in the general population. ${ }^{12}$ Limitations of our research can be different risk factors for inadequate anti-HBs response such as injection not in the deltoid muscle, male gender, obesity, smoking, immunosuppression and specific HLA haplotypes. Additional studies are needed to determine the duration of immunological memory as well as the appropriate time to apply a booster dose of the vaccine. ${ }^{5}$

Due to immunization, as well as overall improvement in preventive measures, Bulgaria has changed its status from high endemic area (with annual incidence rates of approx. 25-35\%000 in the 1980s) to moderate endemic area (with only 302 newly reported cases and annual incidence rate of 
4.1\% 000 in 2013). ${ }^{4}$ According to a recent study conducted in Bulgaria, the prevalence of HBsAg positive individuals up to 19 years vaccinated against HBV is significantly lower, compared with non-vaccinated ones above 20 years old ( $1 \%$ vs. $4.8 \%){ }^{13}$

Our data shows a significant reduction in the number of HBV positive individuals after 15 years of age. Despite recommendations, serological testing of individuals for the presence of anti-HBs antibodies 1 to 2 months after the completion of the main vaccination regimen is not routinely performed. ${ }^{5}$ According to the literature, between $5 \%$ and $14 \%$ of the adults in the general population do not form anti-HBs $\mathrm{Ab}$ after the standard HBV vaccination scheme. ${ }^{14}$ It has been demonstrated a possible genetic predisposition to vaccine non-responsiveness likely due to the presence of specific human leukocyte antigen (HLA) haplotypes and specific single nucleotide polymorphism (rs497916, rs3922, rs676925 and rs355687) in genes of cytokine/cytokine receptors and toll-like receptors. ${ }^{15}$

The antibody concentration to HBsAg is estimated to be $>10 \mathrm{mIU} / \mathrm{ml}(\mathrm{IU} / \mathrm{L})$ to $>100 \mathrm{mIU} / \mathrm{ml}$ (IU/L). ${ }^{16}$ Some authors assume the value of $10 \mathrm{mIU} / \mathrm{ml}$ as positive and protective according to European recommendations. ${ }^{17}$ Other authors assume a higher reference level of $100 \mathrm{mIU} /$ $\mathrm{ml}$ and more than $100 \mathrm{mIU} / \mathrm{ml}^{18}{ }^{18}$ especially when the vaccine is used to protect from occupational risk of contamination with blood and blood products ${ }^{19}$. Individuals with anti-HBs $\mathrm{Ab}<10 \mathrm{mIU} / \mathrm{ml}$ are considered non-responders. There have been studies demonstrating that postvaccinal immunity against hepatitis B is not only humoral, but it has been detected that immunologic memory determined by HBsAg - specific T-lymphocytes persists long time after vaccination in recipients with serum antibodies $<10 \mathrm{mIU} /$ $\mathrm{ml}^{20}$

We have found better immune response after application of hepatitis B vaccine among female gender compared to male gender, as per most of the authors. Men have a reduced response to conventional hepatitis $\mathrm{B}$ vaccines. ${ }^{21}$ There are various mechanisms that explain the more adequate immune response in women. Men and women have different levels of hormones that change over time, further affecting the ability of a person to respond to vaccination. ${ }^{22}$ There is a hypothesis that immunological differences between sexes are due to steroids, especially testosterone, estradiol and progesterone, which affect the functioning of immune cells. ${ }^{23}$ In addition to hormonal influences, genetic and epigenetic factors contribute to differences in the immune response to hepatitis B vaccination based on sex. ${ }^{24}$

\section{CONCLUSIONS}

According to our data post-vaccination immune response is registered in almost $80 \%$ of the investigated children from 6 months to one year old. These results confirm the effectiveness of the vaccine against hepatitis $\mathrm{B}$. The postvaccination immune response is maintained in $67.7 \%$ of the participants up to 15 years and dropped to nearly $40 \%$ after this age. Around $60 \%$ of the vaccinated individuals after 15 years of age have no protective anti-HBs antibody level with unknown post-vaccination immune response. We found that female gender have stronger and prolonged immune response compared to male gender as this can be due to hormonal influences and genetic and epigenetic factors, as well. We recommend an application of a booster dose of HBV vaccine after 15 years of age. For determination of anti-HBs Ab titer, it is advisable to test the anti-HBs Ab levels 1 month after application of the booster dose, especially in people working with biological materials. In spite of the mass immunization against HBV in Bulgaria, the relative share of chronic HBV infection does not show a downward trend. Therefore it is very important to study the duration of post-vaccination immune response.

\section{REFERENCES}

1. WHO. Hepatitis B. Available from: http://www.who.Int/mediacentre/factsheets/fs204/en/. Last accessed April 2017.

2. Atanasova MV, Haydouchka IA, Zlatev SP, et al. Prevalence of antibodies against hepatitis $C$ virus and hepatitis $B$ coinfection in healthy population in Bulgaria. A seroepidemiological study. Minerva Gastroenterol Dietol 2004; 50(1): 89-96.

3. Ciccozzi M, Babakir-Mina M, Lo Presti A, et al. Molecular analysis of hepatitis B virus in Bulgaria. J Med Virol 2013; 85(1): 49-54.

4. Todorova T, Tsankova G, Lodozova N. Hepatitis B infection in eastern regions of Bulgaria. Journal of IMAB 2016; 22(1): 1033-5.

5. Ivanova L, Kyoseva M, Metodiev K, et al. Serologic hepatitis B virus immunity in health care workers. Eur J Inflamm 2013; 11(3): 733-7.

6. Baymakova M, Popov GT, Andonova R, et al. [Hepatitis B virus infection: general characteristics and prevention]. General Medicine 2018; 20(3): 40-6 (Article in Bulgarian).

7. Schweitzer A, Horn J, Mikolajczyk T, et al. Estimations of worldwide prevalence of chronic hepatitis $\mathrm{B}$ virus infection: a systematic review of data published between 1965 and 2013. Lancet 2015; 386: 1546-55.

8. Teoharov P, Kevorkyan A, Petrova N, et al. Immune memory and immune response in children from Bulgaria 5-15 years after primary hepatitis B vaccination. Pediatr Infect Dis J 2013; 32(1): 51-3.

9. Kevorkyan A. [Epidemiological and immunological efficacy of hepatitis B vaccine]. General Medicine 2013; 15(2): 40-7. (Article in Bulgarian)

10. Nardone A, Anastassopoulou CG, Theeten H, et al. A comparison of hepatitis B seroepidemiology in ten European countries. Epidemiol Infect 2009; 137: 961-9.

11. Zampino R, Boemio A, Sagnelli C, et al. Hepatitis B virus burden in developing countries. World J Gastroenterol 2015; 21(42): 11941-53.

12. Norouzirad R, Shakurnia A, Assarehzadegan M, et al. Serum levels of anti-hepatitis B surface antibody among vaccinated population aged 1 to 18 years in Ahvaz city southwest of Iran. Hepat Mon 2014; 14(1): e13625.

13. Kevorkyan A, Teoharov P, Lernout T, et al. Prevalence of HBV and HCV among outpatients in the Plovdiv region of Bulgaria, 2010-2011. J Med Virol 2015; 87: 401-6.

14. Kubba AK, Taylor P, Graneek B, et al. Nonresponders to 
hepatitis B vaccination: a review. Commun Dis Public Health 2003; 6(2): 106-12.

15. 15. Meireles L, Marinho R, Damme P. Three decades of hepatitis B control with vaccination. World J Hepatol 2015; 7(18): 2127-32.

16. Puro V, Caril G De, Cicalini S, et al. European recommendations for the management of health care workers occupationally exposed to hepatitis $\mathrm{B}$ virus and hepatitis $\mathrm{C}$ virus. Euro Surveill 2005; 10(10): 260-4.

17. Roggendorf M, Schulte I, Xu Y, et al. Therapeutic vaccination in chronic hepatitis B: preclinical studies in the woodchuck model. J Virol 2007; 14(1): 51-57 (Abstract).

18. Heininger U, Gambon M, Gruber V, et al. Successful hepatitis B immunization in non- and low-responding health care workers. Human Vaccines 2010; 6(9): 725-28.

19. Kevorkyan A, Teoharov P, Petrova N, et al. Carriers of hepatitis $\mathrm{B}$ and hepatitis $\mathrm{C}$ among medical personnel and protection by vaccine. Probl Infect Parasit Dis 2011; 39(2): 24-6.
20. Kevorkyan AK, Teoharov PB, Petrova NS, et al. Immune response and immunologic memory in medical personnel vaccinated with hepatitis B vaccine. Folia Med (Plovdiv) 2011; 53(3): 32-8.

21. Fernandez-Bernal F, Aguilar-Betancourt A, Aljovin V, et al. Comparison of four recombinant hepatitis $\mathrm{B}$ vaccines applied on an accelerated schedule in healthy adults. Hum Vaccin 2011; 7(10): 1026-36.

22. Fink A, Klein S. Sex and gender impact immune responses to vaccines among the elderly. Physiology (Bethesda) 2015; 30 (6): 408-16.

23. Kovats S, Carreras E. Sex steroid receptors in immune cells. In: Klein SL, Roberts CW, editors. Sex hormones and immunity to infection. Berlin: Springer-Verlag; 2010: 53-92.

24. Klein SL, Marriott I, Fish EN. Sex-based differences in immune function and responses to vaccination. Trans $\mathrm{R}$ Soc Trop Med Hyg 2015; 109: 9-15.

\title{
Оценка иммунного ответа анти-HBs-антител против вируса гепатита В у вакцинированных людей из региона северо-восточной Болгарии
}

\author{
Деница Т. Цанева-Дамянова ${ }^{1,3}$, Лилия И. Иванова ${ }^{1,2}$, Силвия Н. Павлова ${ }^{4}$, Светлана Б. \\ Тодорова ${ }^{5}$, Цветелина К. Попова ${ }^{2,6}$ \\ ${ }^{1}$ Кафедра „Микробиология и Вирусология”, Медицинский университет - Варна, Варна, Болгария \\ 2Лаборатория клинической вирусологии, УМБАЛ „Св. Марина”, Варна, Болгария \\ ${ }^{3}$ Медико-диагностическая лаборатория „Статус”, Варна, Болгария. \\ ${ }^{4}$ Кафедра „Социальная медииина и организация здравоохранения”, Медицинский университет - Варна, Варна , Болгария \\ ${ }^{5}$ Кафедра „Статистика и прикладная математика”, Экономический университет - Варна, Варна, Болгария \\ ${ }^{6}$ Образовательный и исследовательский секторы медицинской лаборатории, Медицинский колледж, Медицинский университет - Варна, \\ Варна, Болгария
}

Адрес для корреспонденции: Деница Т. Цанева-Дамянова, Кафедра „Микробиология и Вирусология”, Медицинский университет - Варна, ул. „Брегалница” № 3, Варна, Болгария; E-mail: dr.tsaneva@gmail.com; Тел: 0878877627

Дата получения: 19 февраля 2019 Дата приемки: 15 апреля 2019 Дата публикации: 31 декабря 2019

Образец цитирования: Tsaneva-Damyanova DT, Ivanova LI, Pavlova SN, Todorova SB, Popova TK. Evaluation of anti-HBs antibody immune response against hepatitis B virus in vaccinated people in North-Eastern Bulgaria region. Folia Med (Plovdiv) 2019;61(4):572-78. doi: 10.3897/folmed.61. e47760.

\section{Абстракт}

Введение: Гепатит В является одним из наиболее значительных патогенов человека, ответственных за большое количество острых и хронических инфекционных заболеваний во всём мире.

Цель: Определить длительность поствакцинального иммунного ответа у лиц, разделённых на пять возрастных групп от 6 месяцев до 20 лет.

Материал и методы: Все обследованные субъекты родились в период между 1999 и 2018 годами и в связи с этим были включены в программу обязательной вакцинации против гепатита В. Для определения серологического маркера anti-HBs Ab мы исследовали 499 образцов сыворотки, взятых у амбулаторных пациентов и пациентов в Университетской клинике «Св. Марина“в Варне. 
D. Tsaneva et al

Результаты: Положительный ответ антител (анти-HBs Ab> 10 мME / мл) был обнаружен у 79,7\% (n = 51) в возрастной группе до одного года, у 70,0\% ( $\mathrm{n}=196)$ субъектов в возрасте от 1 года / 1 месяца до 15 лет и у 39,3\% ( $=33$ ) субъектов в группе в возрасте от 15 лет / 1 месяца до 20 лет. У женщин был лучший ответ после вакцинации, чем у мужчин со статистически значимым различием между полом и титром anti-HBs $\mathrm{Ab}\left(\chi^{2}=24,76, \mathrm{p}<0,01\right)$.

Выводы: Несмотря на массовую иммунизацию против гепатита В в Болгарии, относительная доля хронических инфекций HBV не имеет тенденции к снижению. Поэтому очень важно изучить поствакцинальный иммунный ответ, демонстрируя antiHBs антитела и применять бустерную дозу вакцины по мере необходимости.

\section{Ключевые слова}

anti-HBs Ab, HBV, HBV вакцинация 